\title{
LA VOCACIÓN LITERARIA DE SANTA TERESA
}

El concepto acerca del caso literario de Santa Teresa ha sido siempre el de una clara subordinación dentro de un proyecto vital monopolizado por su experiencia religiosa. Nada, por tanto, más ajeno a sus propósitos que un cultivo deliberado del arte o una valoración positiva de su propia obra, impuesta contra su voluntad por el rigor de la obediencia a sus confesores y prelados. Tarea importuna y menospreciada, conforme a una aceptación literal de multitud de textos que en realidad no son sino tributos pagados a la humilitas retórica ${ }^{1}$. Tanto la obra como sus características se incorporan entonces al más típico esquema hagiográfico y termina por ser puesta a cuenta del mayor de sus milagros. Un milagro ante el que hay que dar de mano porque, a fuer de tal, sería impío o absurdo su trasplante a cualquier oțro terreno. El resultado, tranquilizador para muchos, es que Teresa de Jesús continúa siendo la Santa, no la Escritora.

Hay que afirmar, frente a esto, que (como en todo gran poeta) su caso es único y extraordinario, pero no en sí mismo contradictorio. Las falsas premisas terminaron aquí por of uscar del todo un problema ya dificultoso por su abundancia en refinadas paradojas, donde pierden pie los mal intencionados de antaño y los incautos de hogaño. Porque Santa Teresa constituye un verdadero ejemplo de irrestañable vocación literaria y de un curso creador limpio e impetuoso. Contemplación y literatura vivieron en ella lado a lado, no en actitud de compromiso o de tregua (como ocurrió con Baltąsar Gracián), sino en armónica hermandad y simbiosis. Si su experiencia espiritual dio a su pluma la más fulgurante materia, también su espíritu aprendía a conocerse mejor en aquel cuotidiano ejercicio y no habría llegado donde llegó sin esta otra ascesis de verterse, aquilatado, sobre la página en blanco. Ella supo muy pronto que ciertas cosas no acaban de entenderse a fondo hasta ser puestas por escrito: "Cuando comencé

Conforme a la más pura tradición convencional y devota, estudiada por ERNEST $R$. Curtius, European literature and the Latin Middle Ages, Princeton University Press, Princeton, 1973, pp. 407 ss. 
esta postrera agua a escrivir, que me parecía imposible saber tratar cosa más que hablar en griego, que ansí es ello dificultoso" ${ }^{2}$.

$Y$ en su caso estamos ante una vida atravesada de arriba abajo por la literatura. El dato inicial es aquí el don innato, la fibra hipersensible al estímulo poético, bajo el cual entra a vibrar todo su ser. Porque para ella, como si se tratara de un anticipado personaje cervantino, la literatura es un compromiso total, un juego en serio que tensa el resorte de la acción. Primero será la lectura de vidas de santos la que, en su primera niñez, la induce a una salida quijotesca en busca del martirio que abre las puertas del cielo. Después son los libros de caballerías los que habrán de marcar una peligrosa crisis juvenil. No exagera en esto la autoinculpación de la Vida: su reacción es justamente la que pide aquella literatura embriagadora, de abolengo no cristiano, donde sólo reina la aventura fantástica, caballeresca para el hombre y a morosa para la mujer. Trastorno de su cabeza aún no asentada, que no ya cuaja en devaneos de adolescencia, sino en componer un libro de caballerías: "Diose, pues, a estos libros de caballerías, sino de vanidades, con gran gusto, y gastaba en ellos mucho tiempo; y como su ingenio era tan excelente, así bebió aquel lenguaje y estilo, que dentro de pocos meses ella y su hermano Rodrigo de Cepeda compusieron un libro de caballerías con sus aventuras y fícciones, y salió tal, que había harto que decir de él" " ${ }^{3}$. También don Quijote estuvo a punto de escribir uno de éstos, antes de decidir que era mejor vivirlo. Con su aventura espiritual, Teresa, la en todo extremosa, hizo lo uno y lo otro.

Reducida en el concepto vigente a una pasajera afición a los libros de caballerías que no dejó mucha huella ${ }^{4}$, su deuda con la literatura profana dista de haber sido bien sopesada. Desconocemos el catálogo

2 Vida, 18, 7. Los textos teresianos se citan aquí conforme a la edición de EFRÉN DE la Madre de Dios Y Otger Steggink, Obras completas, 7a. ed., BAC, Madrid, 1982. En adelante EFRÉN -STEOGINK.

3 Francisco de Ribera, Vida de Santa Teresa de Jesús, ed. J. Pons, Gustavo Gili, Barcelona, 1908, p. 99. Originalmente titulada La vida de la Madre Teresa de Jesús, fundadora de las Descalças y Descalços, Pedro Lasso, Sala manca, 1590.

${ }^{4}$ Según A. Morel Fatio, nada en particular de la biblioteca paterna parece haberla impresionado mucho y los libros de caballerías apenas si dejan más huella que alguna desperdigada expresión o giro característico ("Les lectures de Sainte Thérèse", $\mathrm{BH}$, 10,1908, p. 19). Juicio similar en Ramón MenÉndez Pidal, "El estilo de Santa Teresa", La lengua de Cristóbal Colón, Espasa Calpe, Buenos Aires, 1947, p. 138. Panorama de recuerdos más específicos señalados por Marcel Batallion, "Santa Teresa, lectora de libros de caballerías", Varia lección de clásicos españoles, Gredos, Madrid, 1964, pp. 21-23. Incorpora también algunos despuntes de orden conceptual Víctor García de LA Concha, El arte literario de Santa Teresa, Ariel, Barcelona, 1978, pp. 50-54. Para la probable iníluencia de la literatura caballeresca en el símil del castillo interior, ARGIMIro Ruano, Teresa de Ávila clásica, Editorial Edil, Río Piedras, 1972, pp. 41 y 150. EFRÉn J. M. Montalva de LA M. DE Dios menciona el sabor a literatura caballeresca de Las fundaciones (Santa Teresa por dentro, Editorial de Espiritualidad, Madrid, 1973, p. 65). 
de la "biblioteca clandestina"5 que entre ella y su madre reunieron en la casa paterna. Pero sí sabemos que el libro de caballerías era entonces epítome de la literatura de entretenimiento y que sus lectores eran los mismos que devoraban también novelas sentimentales y Celestinas, como solían lamentar moralistas y predicadores ${ }^{6}$. La poesía cancioneril, por otra parte, representaba la experiencia básica y unificadora del gusto literario de la época. Era también el terreno donde autores y público se familiarizaban de primera intención con el análisis introspectivo y sus posibilidades creadoras, tan desarrolladas des pués por la literatura ascético-mística. La autora del Vivo sin vivir en $m i^{7}$ ha

5 Así llamada por Antonio Garcia Figar, "Formación intelectual de Santa Teresa de Jesús", $R E, 4$ (1945), p. 171. Las especulaciones acerca de las lecturas juveniles de la Santa vienen haciéndose a base del inventario de bienes realizado por su padre en octubre de 1507 , a raiz de la muerte de su primera esposa, que publicó Manuel SerraNo y Sanz, Apuntes para una biblioteca de escritoras españolas, BA E, Madrid, 1903, t. 2, pp. 480-488. Los libros de la exigua colección debían de ser viejos y hallarse en no muy buen estado, según la tasación que sólo asciende a un total de mil seiscientos maravedíes. No hay, pues, ninguna garantía de que dichos libros hubieran pasado al segundo hogar de Alonso Sánchez de Cepeda ni estuvieran disponibles durante la primera juventud de Teresa.

${ }^{6}$ Así, por ejemplo, fray Antonio de Guevara: "¡Oh, cuán desviada está hoy la república de lo que aquí escribimos y aconsejamos, pues vemos que ya no se ocupan los hombres sino en leer libros que es afrenta nombrarlos, comoson Amadis de Gaula, Tristán de Leonís, Primaleón, Cárcel de amor y La Celestina, a los cuales todos y otros muchos como ellos se debría mandar por justicia que no se imprimiesen, ni menos se vendiesen, porque su dotrina incita la sensualidad a pecar y relaja el espíritu a bien vivir" (Aviso de privados a despertador de cortesanos, Biblioteca Económica de Clásicos Castellanos, Paris, s. f., pp. 45-46). El jesuíta Franćisco de Ribera no ahorraba tampoco las condenas sobre aquella literatura del diablo: "La primera fue, haciéndola leer libros de caballerías, que es una de sus invenciones, con que ha echado a perder muchas almas recogidas y honestas, porque en casas a donde no se da entrada a mujeres perdidas y destruidoras de la castidad, hartas veces no se niega a estos libros que hombres vanos, con alguna agudeza de entendimiento y con mala voluntad, han compuesto para dar armas al enemigo nuestro, y suelen hacer disimuladamente el mal que aquellas ayudadoras de Satanás por ventura no hicieran" (Vida de Santa Teresa de Jesús, p. 99). Y sin embargo, la misma Madre Teresa no los veía con tan malos ojos en la vida cuotidiána y reconocía su deuda hacia ellos. Así su sobrina María de Ocampo (María Bautista en el claustro) al atestiguar de su inicial falta de vocación: "Llegada a Ávila, cuando la Santa me vio y tan lejos de lo que esperava, sintiólo, mas no para persuadirme a nada, antes cuando me vía leer libros de caballerías y otros semejantes, decía que no le pesava, porque tenía esperanza que de aquellos vendría a leer los buenos, y me aprovecharía esa inclinación, que así havía hecho a ella" (Efrén de la Madre de Dios y Otger Steggink, Tiempo y vida de Santa Teresa, $B A C$, Madrid, 1968, p. 133).

Acerca de las raíces cancioneriles del tema, Dámaso Alonso, "El misterio técnico en la poesía de San Juan de la Cruz", Poesía española, Gredos, Madrid, 1966, pp. 235-242. Ángel Custodio Vega, La poesía de Santa Teresa, BAC, Madrid, 1972, pp. 68-72. Para sus relaciones con dicha literatura y su novelización por Diego de San Pedro, Anna Krause, "El 'tractado' novelístico de Diego de San Pedro", $B H i, 54$ (1952), 245-275. Hilario S. Sáez, "Notas a la glosa 'Vivo sin vivir en mí' de Santa Teresa y de San Juan de la Cruz", $M L Q, 13$ (1952), 405-408. Hay que añadir a Montemayor entre los glosadores de "Ven muerte tan escondida" (El cancionero del 
sabido adueñarse la herencia conceptista de los últimos poetas de cancioneros (Jorge Manrique, Álvarez Gato, Garci Sánchez de Badajoz), igual que su dominio del villancico pastoril de sesgo dramático obliga a postular su conocimiento del Cancionero (1496) de Juan del Encina. Una coincidencia casi literal entre el prólogo del Lazarillo de Tormes y las Meditaciones sobre los cantares ha sido señalada por Eugenio Asensio ${ }^{8}$, perspectiva que, de confirmarse, podría hacer nueva luz sobre los problemas internos del Libro de la vida. He señalado en otro lugar ${ }^{9}$ cómo su característico interés en lo psicosomático la llevó a estudiar, con alta probabilidad, el Remedio de cuerpos humanos (1542) de su ilustre paisano el doctor Luis Lobera de Ávila, un libro de medicina donde pudo hallar también valiosos estímulos para la elaboración del símil del castillo interior.

Santa Teresa llevó una vida de auténtica escritora profesional desde aproximadamente el año 1560 hasta casi los mismos días de su muerte. Veintidós años de febril manejar la pluma, de tarea cuotidiana contra todos los vientos y mareas, en que los proyectos se suceden y ejecutan infaliblemente y sin interrupción. Las últimas revisiones de la Vida (por ejemplo) debieron pisar los talones, o incluso simultanear con la primera redacción de Camino de perfección ${ }^{10}$. Multitud de jornadas agotadoras terminan con un supremo esfuerzo en el cultivo del Epistolario, como imposición ineludible de sus responsabilidades. Pero tam bién rienda suelta a una pasión de escribir, con tantas y tan maraviliosas cartas redactadas sin ningún propósito específico, fuera de un cálido anhelo de la relación personal. Archivos de tanta deliciosa nadería y documentos sobre dimensiones humanas de la época que sin ellas nos serían desconocidas. Porque el malhadado prejuicio hagiográfico ha impedido reconocer algo muy obvio, nunca afirmado hasta

poeta George de Montemayor, ed. A. González Palencia, Bibliófilos Españoles, Madrid 1932, p. 396). Para la tradición profana de otro gran tema teresiano, RAFAEL Ferreres, "La flecha alegórica con que hiere el amor", $H D A$, t. 1,517-524.

8 "Dos obras dialogadas con influencias del 'Lazarillo de Tormes': 'Colloquios' de Collazos, y anónimo 'Diálogos del capón”", CuH, 94 (1973), p. 386. Claro está que el año 1554 y los que siguieron no parecen prestarse a lecturas de esta clase, por coincidir con una gran intensificación de las experiencias místicas de la Santa. No hay que olvidar, sin embargo, que el Lazarillo de Tormes circuló muy probablemente con cierta anticipación a dicha fecha. Un destino curioso condujo a Santa Teresa a ser amiga del expurgador del mismo, Juan López de Velasco, en cuya casa madrileña se hospedaría en 1580 (ErRén-STEgGink, Tiempo y vida de Santa Teresa, p. 634). Reflexio-

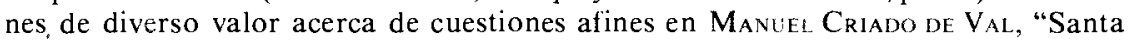
Teresa de Jesús en la gran polémica española: mística frente a picaresca", $R E, 22$ (1963), 376-384.

" "El símil del castillo interior: sentido y génesis", ponencia en el Congreso Internacional Teresiano de Salamanca (octubre, 1982). Actas en curso de publicación.

${ }_{10}$ Es preciso tomar en cuenta las ideas aportadas por fray Tomás de la Cruz para retrasar un par de años (hacia 1566) la fecha tradicionalmente asignada a su primera redacción (Camino de perfección, ed. facsímil, Tipografia Poliglotta Vaticana, Roma 1965 , t. 2, pp. $15 s s)$. 
este momento y que todavía causará escándalo en algunos: Santa Teresa gozaba del placer de crear como una verdadera adicción, especie de bendito "asimiento" de que, por fortuna nuestra, no llegó a ser consciente. Son hasta los médicos quienes han de poner coto al oneroso desbordamiento casi grafómano: "Me ha mandado el doctor que no escriva jamás sino hasta las doce y algunas veces no de mi letra" $(178,1)$. Sus monjas no en vano la ven escribir a altas horas de la noche, con el rostro todo encendido ${ }^{11}$, en trance creador que, muy de acuerdo con sus profundas convicciones, sin duda armonizaba lo divino y lo humano, lo sobrenatural y el puro placer estético.

Cabe afirmar hoy que el canon de los escritos teresianos ha sido ampliado con el reciente descubrimiento ${ }^{12}$ de una obra creada en virtual colaboración con su brazo derecho, el P. Jerónimo Gracián. No es ningún nuevo tratado sobre cosas de oración, sino un curioso librito titulado El cerro, sátira divertidísima contra uno de los problemas que más la preocupaban: los estragos causados por la "melancolía", es decir, las acedías y depresiones, los desequilibrios mentales en fase inicial o no aguda que dan al traste con la piedad y buena marcha de sus conventos" ${ }^{13}$. Cerro ('morrillo de un animal') es un delicioso "teresianismo" para designar la dureza de cerviz, la irracionalidad y tozudez morbosa que afligen a tales enfermos y, sobre todo, enfermas, puestos en llevar la contraria y hacerlo todo al revés. El cerro adopta la forma de unas Constituciones ${ }^{14}$ burlescas, en que se ordena echarlo todo por ese derrotero de la melancolía (único medio, tal vez, de que estos desdichados tomen, por espíritu de contradicción, el buen camino). Hay en la obra un parentesco obvio con el Elogio de la locura de Erasmo y constituye, sin duda, el ápice español de la literatura adoxográfica ${ }^{15}$ o de seudoelogio retórico (y en cuanto tal uno de los géneros humanísticos más puros):

11 Efrén-Sterigink, Tiempo y vida de Santa Teresa, p. 509.

12 Por lldefonso Moriones de la Visitación, "El cerro, obra inédita del P. Jerónimo Gracián", $E C, 16$ (1965), 412-425. Texto completo en el libro del mismo Ana de Jesús y la herencia teresiana, Edizioni del Teresianum, Roma, 1968, apéndice l. Incluido también en el volumen Humor y espiritualidad de la escuela teresiana primitiva, El Monte Carmelo, Burgos, 1966.

13 Sobre el problema de la melancolía en su vida y obra, JUAN J. López IBor, "Ideas de Santa Teresa sobre la melancolía", $R E, 22$ (1963), 423-443. Capítulo "Psiquiatría y ascética. La melancolía" en Nazario de Santa Teresa Ruano, La psicología de Santa Teresa, Editorial Jus, México, 1955. Frinancisco Marco Merenclano, "Psicoanálisis y melancolía en Santa Teresa", Ensayos médicos y literarios, Cultura Hispánica, Madrid, 1958.

${ }_{14}$ El grave problema de las Constituciones en el inmediato futuro de la Descalcez absorbía en aquel momento (febrero, 1582) ios mayores cuidados de ambos (MorioNES, El cerro, p. 417). Sobre las dificultades que en torno a esto venían suscitándose, Fortunato Antolín, "Observaciones sobre las Constituciones de las carmelitas descalzas promulgadas en Alcalá de Henares en 1581", EC, 24 (1973), 291-374.

15 Sobre el concepto retórico de la adoxografía, Arthur A. Pease, "Things without 
Los despenseros y.provisoras sean de gran cerro, apocados, duros y desgraciados, y no les puedan sacar especias para la olla; y den las tajadas de queso transparentes; y sienpre anden llorand o la pobreça de la casa, con una cara de anbre, para que los súbditos questubieren tentados de la relixión, les crezca la tentación y pierdan toda alegría y suabidad de espíritu ${ }^{16}$.

Fray Jerónimo Gracián firmó aquellas páginas bajo el adecuado seudónimo de "Nos Fr. Melanco Zerruno, provincial de todos los melancólicos, tristes y amargos de coraçón, airados, inquietos, escrupulosos, coléricos, insufribles y desasosegados, etcétera" (p. 474). Se escribió la obrita entre enero y febrero de 1582, cuando, como Provincial, acompañaba Gracián a Santa Teresa en la penosísima fundación de Burgos y andaban los dos muy preocupados con el futuro de la naciente Orden. Pero, como observó su afortunado descubridor, el P. Ildefonso Moriones ${ }^{17}$, se comprueba una transparencia general de las ideas de la Santa y puede considerarse El cerro como una colaboración entre ambos. Su calidad es, en efecto, desigual, con fragmentos algo pedestres junto a otros vivacísimos, donde se reconoce la prosa inconfundible de ella. Suelen éstos coincidir, además, con los problemas suscitados por la melancolía de las monjas:

11 Iten, en todas las maneras sean muy mal sufridas nuestras súbditas, y de qualquier cosita que les dixeren, aunque sea de burlas, se sientan, gruñan y encapoten y enbotijen, respondan y se aíren de tal manera, que ellos pierdan la paz y toda la casa ande repuntada con ellas, mirando en cada palabrilla no dalles ocasión; aunque lo ayan hablado con llaneça, tengan que confesar que hablaron palabras desabridas con una hermana, o a lo menos que le dieron ocasión de desabrimiento.

12 Iten, sienpre aya un lenguaje de quién es fulana, de qué casta viene, de qué linaje, si servía o era servido, para que si le dieren en rostro con ello, o se tratare delante della, se desabra y aflija, y si detrás dél se murmurare, lo benga a saber de otros nuestros súbditos, y así nazcan rencores y bandos (p. 500-501).

$Y$, para que la Orden baya en aumento, las novicias que se hubieren de recivir sean beatas; que tengan los ojos torcidos y los ocicos y narices grandes; el color de acelga; los dientes, grandes, llenos de tova; y que, preguntadas de su salud, digan que tienen unos apretamientos destómago, un escarvamiento de coracón. Y que al tienpo que bengan a pedir el ábito, den unos suspiros delicados, la habla con silvito, aleando los ojos al cielo con melindres (p. 504).

honor", $C P h, 21$ (1926), 27-42. Sobre la misma en España, Francisco Márquez Villanueva, Personajes y temas del Quijote, Taurus, Madrid, 1975, p. 210.

16 Moriones, Ana de Jesús, p. 491.

${ }^{17}$ El cerro, pp. $417,422,425$. GRACIÁN, por su parte, escribió también otro Tratado del relajado, contra el cerro (p. 413). 
Bueno será saber que todo ello se ha escrito en días de fracaso humlllante, en medio de un invierno gélido y bajo el asedio ya del cáncer que meses después había de llevársela de este mundo. Naturalmente, ella no tiene idea del Elogio de la locura ni de la literatura adoxográfica. Es Gracián quien le ha explicado un nuevo concepto que, como de costumbre, capta al vuelo y al que se entrega, gozosa, en un juego creador capaz de sobreponerse a las amarguras del cuerpo y del espíritu.

Semejante travesura irónica, conforme a los más puros cánones del humanismo cristiano, viene a dar una coronación perfecta a la obra literaria de Santa Teresa. Representa ésta un corpus íntegramente desarrollado en su triple frente de autobiografía-doctrina-crónica. No es, con certeza, una obra acumulada por los vientos del azar ni por imposiciones arbitrarias o de mera oportunidad. Dicha persuasión choca, sin embargo, con uno de los mitos más desorientadores y tenaces, endurecido por cuatro siglos de hagiografía. Según éste, Santa Teresa sólo escribía contra su voluntad, por pura obediencia al mandato de sus prelados o confesores. Olvida esta mitología que libros de esta densidad de pensamiento no se encargan ni se improvisan, así como otras muchas realidades válidas para toda creación literaria. Desconoce todavía más el carácter de la Madre Fundadora, diestra en salirse con la suya frente a todas las imposiciones, hábil en escurrirse de compromisos importunos y a quien nadie impuso, a la larga, ningún criterio ajeno a sus profundos designios.

Sí es muy cierto que tuvo especial empeño en pregonarlo así, insistiendo una y otra vez en que escribe bajo obediencia y hasta especificando nombres y circunstancias. No es que, en rigor, mintiera, pero la misma rigidez de este patrón debería ya despertar sospechas en el conocedor o aficionado a esta autora tan enemiga de fórmulas. Porque tales declaraciones vienen, en realidad, impuestas como parte de su maniobra defensiva ante la temeridad intrínseca en el hecho mismo de su obra. Sabe ella muy bien que tiene frente a sí los claros textos paulinos sobre el silencio de las mujeres ${ }^{18}$, así como el tradicional papel

18 "Las mujeres cállense en las asambleas, porque no les toca a ellas hablar, sino vivir sujetas, como dice la Ley. Si quieren aprender algo, que en su casa pregunten a sus maridos, porque no es decoroso para la mujer hablar en la iglesia" (I Cor., 14, 34-36). "La mujer aprenda en silencio, con plena sumisión" (1 Timo,, 2, 11). Tambien Tim., 2, 5 cuya invitación "a ser prudentes y honestas, hacendosas, bondadosas, dóciles a sus maridos, a fin de que no sea infamada la palabra de Dios", oía interpretar a su alrededor como un mandato de "encerramiento" contrario a sus actividades de fundadora. Sólo que a tales rigoristas se encargó Dios mismo de rebatirlos: "Parecíame a mí que, pues San Pablo dice el encerramiento de las mujeres-que me han dicho poco ha y aun antes lo havía oído que ésta sería la voluntad de Dios-, dijome: 'Diles que no se sigan por sola una parte de la Escritura, que miren otras, y que si podrán por ventura atarme las manos' "( Cuentas de conciencia, 16. Ávila, julio 1571). Los textos paulinos salían a relucir en todo ataque contra su persona y obra, y así en boca del nuncio Sega: "Fémina inquieta, andariega, desobediente i contumaz, que a título de 
de éstas en los conventículos de alumbrados y la intensa misoginia de la España oficial de la época. Se halla harto persuadida de desafiar a los poderes de este mundo cada vez que toma en su mano la pluma, y esto de escribir por obediencia forma parte de la amplia estrategia de coartada que moldea su obra, igual que el repetido proclamarse ignorante, su recurso a vocablos avillanados ${ }^{19}$ y hasta el guiño de anteponer un "me parece" a sus ideas más atrevidas, como añagaza para quitarse de pendencias con aquellos varones que tienen "letras muchas" (Moradas, V, 1,8).

Todas estas "obediencias" no es que sean falsas. Por el contrario, ha tenido buen cuidado de procurárselas de antemano para no aparecer culpable de iniciativa en lanzarse a escribir por cuenta propia sobre semejantes materias. Hablando con propiedad, habría que llamarlas más bien "licencias" privadamente obtenidas en aval de sus proyectos literarios. Aunque se trate de una hábil manipulación, el calculado desliz en el uso del vocablo podría pasar siempre como harto disculpable en el cuadro de aquel escribir "desconcertado" y "sin letras". Es un buen ejemplo de las exigencias funcionales a que sólo aquel estilo (y no ningún otro) podía dar curso franco. Conocedora del caletre escolástico y cerradamente legalista de los "jueces del mundo"(léase inquisidores), no iba a dejarse ella atrapar en meras palabras, campo de elección en el que era infinitamente más diestra.

Se ha señalado ya también su raro talento para "inventar obediencias" 20 . En Camino de perfección hay, en efecto, una "licencia" del confesor fray Domingo Báñez junto a un doblegarse a cierta peregrina "obediencia", que no resulta ser otra que la de sus propias monjas, súbditas de San José de Ávila, “que me he determinado a las obede-

devoción inventaba malas dotrinas, andando fuera de la clausura, contra el orden del Concilio Tridentino i Prelados: enseñando como maestra, contra lo que San Pablo enseñó, mandando que las mugeres no enseñasen" (Ludovico SAGGl, "Vetera et nova'nella biografía di S. Teresa", Carmelus, 18, 1971, p. 148). La corona de espinas del alegato literal de estos textos perpetuó su eficacia hasta 1922, cuando el pontífice Pío XI negó una proclamación oficial de su doctorado con su famoso obstat sexus (Valentino M acca di S. Maria, "Il dottorato di Santa Teresa", EC, 21, 1970, 103-104). El eterno obstáculo de los textos paulinos fue de nuevo remitido a una comisión teológica (esta vez con resultado favorable) con anterioridad al reconocimiento del doctorado por Paulo VI en 1970 (TOMÁS DE LA CRUZ, "Glosa a la bibliografía del doctorado teresiano", EC, 22 1971, pp. 504-505 n.). Para la exégesis moderna de dichos textos, Pedro Barbagli, "El pensamiento de San Pablo sobre la mujer cristiana en la Iglesia", $R E, 29$ (1970), 331-361.

19 Felicidad Bernabeu Barrachina, "Aspectos vulgares del estilo teresiano y sus razones", $R E, 22$ (1963), 359-375. La tesis de responder con su desaliño léxico al deseo de ocultar su ascendencia judía es admisible sólo de un modo indirecto. Su gran preocupación en esto era la de no parecer "letrada" ni acercarse a los estilos del didactismo al uso, lo cual de por sí la hubiera entregado inerme a la vindicta inquisitorial.

20 Anselmo Donazar Zamora, "Santa Teresa de Ávila, signo de revolución", $R E, 29$ (1970), p. 459 . 
cer" ${ }^{21}$ en sus ruegos de que les hable de oración. En efecto el libro comienza orientado, muy en el cometido de una priora, hacia el explicar la regla. Santa Teresa parece también como atada a una promesa de tratar solamente de oración vocal, pero cuando surge la idea de que toda oración que no sea un mero recitado mecánico es en sí de orden mental, termina por hablar de cuanto le place. Sólo que, comprensiblemente, Báñez nunca dio su aprobación al libro (que hasta el final aseguraba no conocer), a pesar de los esfuerzos de ella por mantener la impresión de lo contrario ${ }^{22}$.

${ }^{21}$ Así en la versión de Valladolid. El texto escurialense era algo menos explícito: "Y, como digo, ha sido tanto el deseo que las he visto y la importunación, que me he determinado a hacerlo" (Prólogo, 1). Aunque un poco más abajo admitía: “. . y yo no havré perdido nada en obedecer a estas siervas de Dios". En otras palabras, el texto revisado de Valladolid remacha esta idea de "obediencia" a sus monjas.

${ }^{22}$ Contra la corriente de una tradición multisecular, la crítica del $\mathbf{P}$. Tomás de la Cruz en su citada edición de Camino explica la veracidad con que Báñez podía declarar en el proceso de 1591 no conocer aquel libro (p. 106). Se ponen también de relieve los esfuerzos de ella por presentarlo como sujeto a una anticipada aprobación de Báñez, a un cuando se había desvanecido toda esperanza de lograrla (pp. 66, 74, 84 , 103). La censura corrió, de hecho, a cargo de otro dominico, el P. García de Toledo, que aun siendo mucho menos estricto que Báñez, exigió con todo tal número y calidad de correcciones como para hacer necesaria la nueva versión vallisoletana (pp. 74 ss.) La actitud de la Santa sólo es comprensible como empeño desesperado en a mparar su libro bajo el prestigio del gran teólogo, cuya palabra era ley para la Inquisición, Respecto al mismo Báñez, es ahora obvio que en todo momento se ha negado a tener nada que ver con aquella obra. Su proceder se comprende sin mayor dificultad, pues bastará tener en cuenta las intenciones (ingenuamente confesadas en el prólogo) de alistar a sus monjas en una maniobra con miras a acorralar a Báñez hacia una licencia para una mayor circulación de la Vida, que éste mantiene bajo secuestro virtual. No sabemos lo que ella pudo considerar como "licencia" para lanzarse a escribir aquel nuevo libro cuyo gradual derivar de un comentario de la regla a un tratado de mística pudo bien entenderse como un abuso de aquélla o de la clase de acuerd o que hiciera sus veces. Si se tiene en cuenta el general atrevimiento de Camino de perfección, su agresividad o poco menos en el ataque a inquisidores y letrados y a la política de guerras religiosas, a sí como su ardiente feminismo, se comprende que Báñez (siempre al tanto de su contenido) abdicara de toda responsabilidad acerca de semejante libro. Le convenía poder jurar en cualquier momento que no lo había aprobado ni aun siquiera leído. Ello venía a ser, además, una prudente actitud de "no meneallo", que le libraba también de una condenatoria ruptura con la autora y de crearle así a ésta una situación de muy serias e imprevisibles consecuencias. Aun después de muerta la Santa, todo el asunto continuaría ligado a recuerdos poco gratos, lo mismo que tampoco le animaba a su lectura el verlo impreso por fray Luis de León', uno de sus enemigos académicos. Contra la idealización de las relaciones entre ambos en el libro de Marcel Lépée (Bañez et Sainte Thérèse, Desclée de Brouwer, Paris, 1947), es obvio que aquéllas pasaron por más de un momento difícil. Siempre se ha sabido de la reconocida doblez con que ella recabó a sus espaldas la aprobación de San Juan de Avila para el Libro de la vida, pero también una carta de 1574 se queja del mal humor ("melancolía”) de otra de éste: “¡Oh, qué melancólica viene la carta de mi padre!"(68, 5). Báñez desaprobó de primera intención Las Moradas, según carta de Gracián de enero de $1580(305,12)$. E incluso el dictamen de Báñez sobre la Vida para la Inquisición muestra (aun siendo favorable) una medida de recelo y despego hacia 
No hay que eliminar en algún otro caso circunstancias de hábil diplomacia para que le manden lo mismo que ella desea escribir. Véase, si no, lo ocurrido con nada menos que Las Moradas, hallándose en Toledo con el P. Gracián, aquel su joven "prelado" al que amaba maternalmente y cuyos resortes psicológicos conocía a la perfección. Son días sombríos para la Descalcez y ambos se consuelan hablando de cosas espirituales, pero al llegar a cierto sutil deslinde ella suspira: "OOh, qué bien escrito está ese punto en el libro de mi vida que está en la Inquisición!" Gracián, que ni conocía el libro ni tal vez esperaba rescatárselo nunca al Santo Oficio, dice entonces a la Madre: "Pues que no le podemos haber, haga memoria de lo que se le acordare y de otras cosas, y escriba otro libro" ${ }^{23}$. Pero varios meses antes, el $17 \mathrm{de}$ enero de 1577 , informaba en carta a su hermano Lorenzo de su proyecto de completar (o mejor, superar) el libro de su Vida: "Al obispo envíe a pedir el libro, porque quizá se me antojará de acabarle con lo que después me ha dado el Señor, que se podría hacer otro y grande, y si el Señor quiere acertase a decir; y si no, poco se pierde" $(173,26)$. Nuestra pérdida habría sido ciertamente inmensa, pero a quien afirme que Las Moradas vienen de una orden del P. Gracián, habríase de responder que no conoce la naturaleza femenina.

Sin duda hay que considerar a la Vida como su obra más adventicia. Crece ésta en etapas de revisión y ampliación de cuentas de conciencia requeridas por confesores deseosos de proceder sobre seguro, con incidencias que sólo cabe hoy reconstruir a grandes rasgos ${ }^{24}$. Pero su misma extensión supone un desbordamiento del modelo escueto de la "cuenta de conciencia" bastante para desmentir por sí solo el simple propósito de hacerse entender de sus confesores ${ }^{25}$, quienes jamás

Santa Teresa, como observa Enrique Llamas-Martinez, Santa Teresa de Jesús y la Inquisición española, Academia de Doctores, Madrid, 1970, p. 29.

${ }^{23}$ EFRÉN-Steggink, Obras completas, p. 363 . Se fecha esta conversación el 28 de mayo de 1577 .

${ }^{44}$ Resumen de sus complejas vicisitudes en el profundo estudio de ENRIQUE Llamas MARTinez, Santa Teresa de Jesús y la Inquisición española, C.S.I.C., Madrid, 1972, pp. 228-236. Visión complementaria de Jeannine Poitrey, "¿Qué es el Libro de la vida de Santa Teresa?", $T E, 23$ (1979), 91-107. Como punto de partida, especialmente logrado en el aspecto de su división interna, Rodolphe HoornaERT, Saint Thérèse écrivain Desclée de Brouwer, Paris, 1922, pp. 398 ss.

${ }^{25} \mathrm{La}$ latente finalidad magistral y proselitista aflora en los bruscos cambios de postura narrativa, como el interesantísimo acerca de sus "cinco": "Este concierto querría hiciésemos los cinco que al presente nos amamos en Cristo, que como otros en estos tiempos se juntavan en secreto para contra su Majestad y ordenar males y herejías, procurásemos juntarnos alguna vez para desengañar unos a otros y decir en lo que podríamos enmendarnos y contentar más a Dios" (Vida, 16, 7). Según EfrénSteggink (nota en su edición) los aquí aludidos se identificarían como García de Toledo, Domingo Báñez, Gaspar Daza y Francisco de Salcedo, siempre con la cauta reserva "de ser, en 1565". Pero, aparte de la inseguridad de la fecha, no parece verósímil que extendiera también a Báñez esa clase de "confianzas". Para J. Poitrey los "cinco" eran varios más, con Salcedo, los sacerdotes Daza y Álvarez, el superior 
podían esperar nada semejante, pero tampoco poner falta en ello. El tratado de oración allí incluido (ce. XI-XXII) podría constituir obra aparte y acusa una clara "voluntad de libro", esto es, de alzarse a emular a su modo los grandes libros espirituales que ya había leído. Por encima del interrogante de una primera versión para siempre perdida, es forzoso pensar en una larga historia de previas tentativas como explicación de tanta maestría. Por lo pronto su "prehistoria" textual retrocede continuamente y alcanza ya al año $1555^{26}$, aunque otros prefieran obviar el problema por la repentina llegada de un carisma de "efabilidad" 27 , tesis de una comodidad indiscutible.

Ahora bien, la misma Vida concede todo el condigno relieve a su encuentro con la literatura espiritual, cuando su tío Pedro Sánchez de Cepeda le da a leer en Hortigosa (otoño de 1538) el Tercer abecedario espiritual de fray Francisco de Osuna. Su efecto sobre ella es la sacudida profunda que siempre le causa el contacto de un gran libro: "Y ansí holguéme mucho con él, y determinéme a siguir aquel camino con todas mis fuerzas" (4,6). En 1554 son las Confesiones de San Agustín las que le producen la misma habitual conmoción: "Estuve por gran rato que toda me deshacía en lágrimas, y entre mí misma con gran afleción y fatiga" $(9,8)$. Quiere decir que su conversión a la vida contemplativa no dejó de hallarse marcada, como otras grandes crisis de su existencia, por un marcado cariz literario. Pero si no vaciló en lanzarse por la vía que le señalaban aquellos libros candentes, ¿cuánto tiempo se resistiría para tomar, a su ejemplo, la pluma, aunque no fuera sino para entenderse mejor a sí misma y a su invasora oración? Como se ha visto, los primeros esbozos de la Vida se hallan cronológicamente al filo de su lectura de las Confesiones.

jesuíta Gaspar de Salazar, los dominicos Ibáñez y García de Toledo, doña Guiomar de Ulloa y San Pedro de Alcántara, asumiendo que se trate de un resto textual de la primera versión, sobre todo por la curiosa ausencia de ninguna otra monja en el supuesto grupo (“¿Qué es el 'Libro de la vida'de Santa Teresa?”, p. 103). En todo caso, el texto no puede ser muy posterior a 1559 y sus grandes autos de fe, claramente aludidos.

${ }_{26}^{6}$ Llamas, Santa Teresa de Jesús y la Inquisición española, p. 229. Se ha mencionado su actividad epistolar como preparación previa para su obra doctrinal (JUAN MARICHAL, "Santa Teresa en el ensayismo hispánico", La voluntad de estilo, Seix Barral, Barcelona, 1957, p. 114). Se opone a tal conjetura la escasa oportunidad que para ello ofrecía la vida de la Santa anterior al proceso de fundaciones, así como el hecho de que, en lugar de los "millares de cartas" aquí postulados, el Epistolario sólo registre dos anteriores a diciembre de 1563 .

27 Melquiades Andrés Martín, "Teresa y Juan de la Cruz: proceso de clarificación de la mística", $R E, 36$ (1977), 481-491. "Sabe también que todos no poseen -como ella--la gracia de expresar lo inefable", concedida "después de años de balbuceo y de impotencia expresiva” (Poitrey, “QQué es el 'Libro de la vida’ de Santa Teresa?”, p. 106). “El libro brotó de un carisma especial que Teresa consiguió para comunicar sus vivencias" (DÁmaso Chicharro, introducción al Libro de la Vida, Ediciones Cátedra, Madrid, 1979, p. 74). Sobre su gratia sermonis Valentino Macca Di S. Maria, "II dottorato di Santa Teresa", EC, 21 (1970), p. 39. 
La Vida no oculta el temprano despertar de sus afanes de proselitismo espiritual, comenzando por su propio padre, poco antes de la muerte de éste a fines de 1543: "No fue sólo a él, sino a otras algunas personas las que procuré tuviesen oración. Aun andando yo en estas vanidades, como las vía amigas de rezar, las decía cómo ternían meditación, y las aprovechaba, y dávales libros" $(7,13)$. No es posible eliminar, en una situación de esta clase, por lo menos el conato de dar por escrito tales instrucciones o "aprovechamientos", de pasar del libro ajeno al propio. Nótese que con ello se pisa la misma sociología literaria de los grupos de alumbrados, causante, por ejemplo, del tono descuidado y semifamiliar de la obra religiosa de Juan de Valdés, exclusivamente destinada ad usum nostrorum. Sólo que Santa Teresa aprendió a escribir para todos sin renunciar a los valores expresivos de la intimidad, lo mismo que salvó para la ortodoxia el misticismo más abiertamente carismático. Cruzó ambas fronteras al concebir la idea de la Descalcez, en los albores de la década de 1560.

Si las "obediencias" se presentan como un problema especial dentro de cada obra, no cabe duda que algunos de sus proyectos le resultaron sumamente penosos, como ocurrió con la vasta empresa de Las fundaciones $^{28}$. Según lo dicho por ella misma, le fue impuesta por el $\mathbf{P}$. Jerónimo Ripalda en Salamanca, el año 1573. Pero una de sus Relaciones o Cuentas de conciencia especifica que fue Dios mismo quien, en Malagón y en febrero de 1570, le ordena "que escriviese la fundación destas casas" $(6,2)$. Dicho mandato la decidió a tomar, para en adelante, ciertos apuntes de lo ocurrido en cada fundación, sin duda como labor preparatoria ${ }^{29}$. Se usaron después estos materiales para elaborar la versión definitiva y la existencia avanzada del proyecto y de las fuentes para llevarlo a cabo fueron sin duda conocidas y la causa más directa del otro humano mandato.

Pero hay también una obra particularmente dificultosa en su adscripción a ninguna clase de obediencias humanas. Es lo que ocurre con

${ }^{28}$ Es el libro que escribió tal vez con menos gusto. Para un resumen de sus costosas etapas, véase la nota preliminar de Efrén-Steggink en su edición (p. 517). Hoornaert encarece el carácter torturado de su caligrafía (Sainte Thérèse écrivain, p. 430).

${ }_{29}$ De ahí lo que escribía a su hermano Lorenzo en julio de 1576 , con notables datos acerca de la cuidadosa guarda de sus papeles: "Ya digo a la supriora la envíe [una arquilla] a vuestra merced por que saque de ella los papeles de las Fundaciones y envueltos en un papel y sellados los envíe a la supriora... y no querría los viese nadie (y por eso quiero vuestra merced los saque, que de él no se me da nada) y por los mesmos de las 'Fundaciones'. Quebróse la llave de la arquilla; descerrájese y guá rdela vuestra merced en un arca hasta que se haga la llave. En ella está una llave de un portacartas que digo envíen a vuestra merced, que también están en él algunos papeies-a lo que creo-de cosas de oración. Bien las puede leer y sacar de allí un papel en que están escritas algunas cosas de la fundación de Alva. Envíemele vuestra merced con esotros, porque el padre visitador [Gracián] me ha mandado acabe las 'Fundaciones' y son menester esos papeles para ver lo que he dicho y para esa de Alva" (Epistolario, III, 7-8). 
sus Meditaciones sobre los cantares, tal vez su escrito de génesis más oscura. Aunque ella también aquí se refiera ambiguamente al "parecer de personas a quien yo estoy obligada a obedecer"(Prólogo, 3), no hay modo de averiguar qué eran tales "pareceres" ni quiénes aquellas "personas". Lo más lógico es que ningún confesor ni prelad o fuera tan insensato como para ordenarle la temeridad de comentar (iy en qué términos!) lo que se le alcanzaba del Cantar de los cantares. Fray Luis de León debió de sentir escalof ríos ante aquel librito, que con significativa prudencia eliminó de su edición de $1588^{30}$. La aprobación que el $\mathbf{P}$. Domingo Báñez le otorgara en $1575^{31}$, con el proceso de fray Luis en plena marcha, deberá contarse entre los actos de valentía intelectual de todos los tiempos. Según la tradición, mostró Santa Teresa las Meditaciones, ya tardíamente, en 1580, a su confesor el dominico Diego de Yanguas, quien, como es natural horrorizado, le mandó quemar el libro. Y así lo hizo ella, sin mediar más palabra, en la lla ma de una vela que a la sazón los alumbraba.

Pero las Meditaciones sobre los cantares no se perdieron, porque existían otras copias y si la noticia es, como parece, cierta, todo quedó en un magnífico gesto a lo Sarah Bernhardt. Porque es innegable que amaba la propia obra hasta en la materialidad de sus manuscritos, con los que tomaba la molesta precaución de llevarlos consigo en sus

${ }^{30}$ Las Meditaciones permanecieron desconocidas hasta ser editadas por el $\mathrm{P}$. Gracián en Bruselas en 1611 (fuera de la Península, aunque en tierras de la monarquía española). Las Meditaciones o Conceptos desaparecieron de las obras de Santa Teresa a raiz de una prohibición general dada en 1632 contra toda suerte de comentarios del Cantar de los cantares (E. Allison PeErs, Studies of the Spanish mystics, Sheldon Press, London, 1930, t. 2, p. 165). Por lo demás, se da una curiosa armonía preestablecida entre las ideas bíblicas de fray Luis y Santa Teresa. El miedo al texto bíblico y el refugio en los sentidos alegóricos (¡aquel "beso”!) les merecían idénticas reflexiones: "He oído a algunas personas decir que antes huían de oirías. ¡Oh, válame Dios, qué gran miseria es la nuestra!, que como las cosas emponzoñosas, que cuanto comen se vuelve en ponzoña, ansí nos acace, que de mercedes tan grandes como aquí nos hace el Señor... hemos de sacar miedos, y dar sentidos, conforme al poco sentido del amor de Dios que se tiene" (Meditaciones, 1, 3). Fray Luis recurría también a la misma imagen de la ponzoña: "De las calamidades de nuestros tiempos, que, como vemos, son muchas y muy graves, una es, y no la menor de todas, muy ilustre señor, el haber venido los hombres a disposición que les sea ponzoña lo que les solía ser medicina y remedio" (De ios nombres de Cristo, prólogo). Tal coincidencia en el lamento responde probablemente a lo que sotto voce debía de oírse entre espirituales. Reflexiones sobre algunos de estos problemas en Elizareth T. Howe, "St. Teresa's 'Meditaciones' and the mystic tradition of the "Canticle of canticles", Renascence, 33 (1980), 47-64. Por lo demás, la cuestión tenía profundas raíces teológicas, que habían atlorado en el arzobispo Carranza y fueron objeto de mucha discusión en el círculo español de Lovaina, con Furió Ceriol y las enseñanzas de Bayo, según informa Ignacio Tellechea. "Españoles en Lovaina en 1551-58. Primeras noticias sobre el bayanismo", $R E T, 23$ (1963), 21-45.

31 Efren-Steggink, Tiempo y vida de Santa Teresa, p. 333. 
viajes $^{32}$. A pesar de su proverbial rapidez y descuido de ejecución, sus principales obras conocieron varias redacciones (Vida, Camino, $\mathrm{Me}$ ditaciones) o fueron revisadas con todo escrúpulo (Moradas), lo cual nos ha legado insolubles problemas textuales (como en el caso de Camino de perfección), a la vez que un tesoro de originales y de copias depuradísimas. Se tomará, acorde, exquisito cuidado en proteger el códice de Las Moradas del sino inquisitorial de la Vida. A una y otra se referirá bajo el criptónimo de joyas, pues, aunque esta última siga en poder del Santo Oficio, el nuevo libro "le hace muchas ventajas; porque no trata de cosa, sino de lo que es Él, y con más delicados esmaltes y labores; porque dice que no sabía tanto el platero que la hizo entonces, y es el oro de más subidos quilates, aunque no tan al descubierto van las piedras como acullá. Hízose por mandado del 'vidriero', y parécese bien a lo que dicen" (Epistolario, 209, 10). Una vez más, es Dios, y no los hombres, quien manda en su obra literaria.

Contra todo lo que se ha dicho, Santa Teresa añoró toda su vida el verse en letra impresa. No otra explicación tiene, hasta en su presentación material ${ }^{33}$, el códice de Valladolid de Camino de perfección, cuidadosamente preparado para la mesa del tipógrafo. La ocasión no se presentó hasta ser nombrado coadjutor del arzobispado de Évora su amigo don Teotonio de Braganza, buenísima persona y el único alto eclesiástico con el que tuvo una relación de plena confianza. Fue ella quien entonces le pidió "encarecidamente lo mandase imprimir" ${ }^{34}$, y él quien la "obedeció", puntual, con el Camino de Évora, cabeza de la bibliografía teresiana. El libro impreso como sueño de una vida en las Letras. Dicha y recompensa que no llegó a tener en sus manos por la cruel fatalidad de unos cuantos meses.

Como observa el P. Enrique Llamas ${ }^{35}$, es posible que se hiciera

32 Santa Teresa, Obras completas, ed. Efrén de la Madre de Dios y Otilio del niño Jesús, $B A C$, Madrid, 1954, t.2, p. 29. Fortunato de Jesús Sacramentado, "Influjo de los escritos teresianos antes de la beatificación de la Mística Doctora", EC, 21 (1970), p. 369. Sobre las precauciones unidas a la difusión y conservación del Epistolario Juan L. Astigarraga, "Las cartas de Santa Teresa a Jerónimo Gracián", EC, 29 (1978), 100-176.

${ }^{33}$ Santa Teresa puso en él toda la pulcritud caligráfica de que era capaz y hasta marginó sus cuadernillos a semejanza de un emplanado tipográfico. Como observa fray TomÁS DE LA CRUz: "Todo ello evidencia el esmero con que la Santa se propuso ofrecer a sus monjas un auténtico libro; manejable, bien presentado y de fácil lectura" (Camino de perfección, ed. cit., p. 86). Pero creo que es preciso ir un paso más allá: un perfecto ejemplar de impresor y un sucedáneo del libro en letra de molde, amado por ella hasta un extremo material.

${ }^{34}$ Efren-Steggink, Obras completas, p. 195. Se impone rendir tributo a la perfección de la jugada con que, tanto ella como su Camino, se ponen a cubierto en este arriesgado paso. El libro se imprimirá en otro reino, fuera de la inmediata jurisdicción del Santo Oficio español y bajo el patronazgo de un prelado que es miembro, para colmo, de la familia real portuguesa.

${ }^{35}$ Santa Teresa de Jesús y la Inquisición española, p. 242. Como aquí se observa, el 
vanas ilusiones de publicar su Vida en 1568. No ocultaba a sus amigos que sus obras harían gran provecho después de su muerte, le halaga que incluso se las comparen con las Escrituras y, desde luego, le fastidia muchísimo que se las censuren y enmienden ${ }^{36}$. Tampoco iba a disimular la admiración hacia sus propios libros, pues para eso los consideraba como obra de Dios por su mano. En 1596 una de sus monjas (Isabel de Santo Domingo) declara cómo "algunas veces le dicía la Santa, leyéndola lo que en el libro había escrito, que no pensaba que había de salir tan bueno, ad mirándose de que, sin haberlo pensado, saliese con tanto concierto, y más siendo de cosas tan altas las que escribió" ${ }^{37}$. Confesión, por tanto, de una conciencia estilística entregada, igual que en lo humano, al ideal de "llaneza y claridad, por la que soy perdida"(Epistolario, 120,2). Porque si su vuelapluma daba de sí tanto "bueno", había que dejarlo entonces donde estaba, y de ahí que ni las revisiones impuestas por las inagotables suspicacias de los

Maestro Ávila responde negativamente a un sondeo sobre la eventual conveniencia de una más amplia circulación de la obra. Los discípulos del Maestro lo entendieron perfectamente, pues la rúbrica de la carta no puede ser más explícita en este punto: "Enviada en tiempo que tenía algunas perturbaciones y persecuciones acerca de un libro que le decían sacase a luz"(Obras completas del Beato Juan de Avila, ed. L. Sala Balust, $B A C$, Madrid, 1952, t. 1, 158, p. 805). Santa Teresa puso en toda esta gestión un interés tozudo y angustiado, como muestra José ViCENTE Rodriguez, "Pequeñeces teresiano-sanjuanistas", $R E, 38$ (1979), 419-430. Pero es preciso recordar, además, que para esa fecha (1568) las dudas acerca de su espíritu habían quedado definitivamente atrás, pues ella misma afirma que las experimentó por última vez a raíz de su fundación del convento de San José (1562). La verdadera causa de su ansiedad y de su arriesgada diplomacia se explica perfectamente como relativa a la suerte de su libro. Convencida, al cabo de varios años, de la imposibilidad de arrancar a Báñez un público aval para su libro, concibe el atrevido proyecto de apuntalarlo, a espaldas de aquél, con la aprobación del Maestro Ávila (maravillosa fusión de"let rado"y "espiritual") y tal vez también de San Luis Beltrán (como cree aquí Llamas). No podía prever que su maniobra estaba condenada al fracaso, pues. Ávila era, por principio, aún más opuesto que Báñez a la divulgación de toda experiencia carismática. La bella y afectuosa carta del maestro, tan cercano ya a su muerte, resultaba tajante en este punto y debió decepcionarla profundamente. La aprobación de su espíritu, finalidad secundaria y casi un pretexto no era lo que de veras iba buscando.

${ }^{36}$ Ana de Jesús Lobera habla de su mal velada contrariedad en tan frecuentes casos: "Cuando venían a sus manos [los traslados], decía: 'Dios los perdone a mis confesores, que dan lo que me mandan escribir, trasladándolo y truecan algunas palabras, que ésta y ésta no es mía'. Y luego las borraba y ponía entre renglones de su letra lo que habían mudado." (Francisco de Ribera, Vida de Santa Teresa de Jesús, p. 645). El P. Diego de Yepes escribía a fray Luis de León: "Hablándole una vez de su libro Camino de perfección, holgóse mucho que se le alabase, y dijo con mucho contento: Algunos hombres graves me dicen que parece Sagrada Escritura" (Dichos de Santa Teresa en Obras completas, ed. Efrén Steggink, t. 3, 122, p. 884). Según el mismo Yepes, "se holgaba que le alabasen sus escritos y que estimasen en mucho su Orden, porque como eran doctrina y obras reveladas, le pareció que en alabar sus libros se alababa a Dios" (Fortunato de Jesús Sacramentado, "Influjos de los escritos teresianos", p. 278).

37 Efrén de la Madre de Dios, "Bases biográficas del doctorado de Santa Teresa", $E C, 21(1970)$, p. 33. 
"letrados", dieran al traste con aquel "concierto" que nacía del señorío, y no del estudio. El lamento por su "estilo tan pesado" (Fundaciones, pról., 3) y sus continuas excusas por el "desconcierto" de sus páginas representan, pues, un simple lugar común retórico, doblado de estrategia pro vita sua. Pero no dejan de ser también maniobra femenina de solicitar un piropo para lo más bello que posee: aquella prosa que el $\mathrm{P}$. Maestro fray Luis de León calificaría de "la misma elegancia" ${ }^{38}$. Porque aquel absoluto y máximo hombre de escuelas, que escribía contando las letras, comprende perfectamente el arte, tan opuesto, de Santa Teresa. Y hasta lo envidia como una frontera para él inasequible.

Y además, el arte de escribir es un gran tema por estudiar en su obra. Santa Teresa no sólo borda sus páginas, sino que se las autocrítica y apostilla, entrando y saliendo por ellas en el papel zumbón del escritor metido en faena. A fuerza de humor y de encanto incorpora así, de un modo que habría que llamar ya "cervantino", el proceso creador como elemento temático de la obra creada. La misma teoría se desgrana así entre bromas y veras. Santa Teresa, por ejemplo, se halla muy persuadida de que la metáfora resume en sí y corona todo el arte de la pluma. De ahí que la "comparación", como ella dice, se le antoje algo tan superior y exquisito que, a título de fruta prohibida, teme se halle también vedado para una mujer de su tiempo: "Havré de aprovecharme de alguna comparación, aunque yo las quisiera escusar por ser mujer", dice en la Vida $(11,6)$ cua ndo pasa a exponer el bellísimo símil de las "aguas". Por otra parte, la capacidad de iluminación int uitiva de la metáfora no deja alternativa a la mujer que escribe de aquellas cosas para otras mujeres: "Mas nuestra torpeza de las mujeres todo lo ha menester, y ansí por ventura quiere el Señor que vengan a nuestra noticia semejantes comparaciones" (Moradas, I, 2, 6). Y por supuesto que no renunciará al goce de esas comparaciones suyas, tan sesudamente líricas: las aguas, los palomarcitos, las dos velas, la palomica. Más aún, su progreso como escritora se deja medir por su actitud hacia el símil, que va desde la cautela algo indecisa de la Vida hasta la presentación ex abrupto del deslumbrante castillo interior que cubre todo el libro de Las Moradas. Igual que a cualquiera de la profesión, el desprender una buena imagen le resulta motivo de euforia, sólo que ella no se recata, si a mano viene, de pasar juicio o de congratularse en público por el acierto. "Regálame esta comparación" (Vida, 14, 10), confiesa acerca del símil del vergel bien regado. $O$ "en estremo me parece le viene a el propio esta comparación"(Vida, 17,6). Y lo mismo en el "ensanchamiento" de su maestría al llegar a Las Moradas, uno de cuyos capítulos "declara la oración de unión por una comparación delicada" $(\mathrm{V}, 2)$, que no es sino la de "sus maravillas de cómo se cría la

${ }^{38}$ Caria-dedicatoria en su edición de Obras de la Madre Teresa (Salamanca, 1588), en Obras completas castellanas, ed. F. García, BAC, Madrid, 1957, t. 1, p. 909. 
seda" (V, 2, 2), aunque sólo la conociera de oídas. Y más allá: "Paréceme es la mejor comparación que he acertado a decir" (VI, 2,4). La otra faceta de esta actitud semilúdica confiesa con la misma espontaneidad el imaginado fracaso: "Riéndome estoy de estas comparaciones, que no me contentan; mas no sé otras. Pensad lo que quisierdes; ello es verdad lo que he dicho"(VII, 2, 14). "Y aunque sea grosera comparación, yo no hallo otra que más pueda dar a entender lo que pretendo" $(V, 4,3)$. En su concepto valorador de la metáfora constituye ésta el último límite o posibilidad de la expresión: "No hacía sino poner comparaciones para darme a entender" ( Vida, 27,3). Y lo que aquélla no alcance a decir quedará para siempre en el arcano: "Sentí en mi espíritu un no sé qué, que antes ni después no me acuerdo haverlo con nadie sentido, ni yo sabré decir cómo fue, ni por comparaciones podría" ( Vida, 33, 9). Y en el fondo, por lo que hace a sí misma, sabe bien a qué atenerse, guiada del juicio del más seguro y mejor de los críticos, pues no en vano le ha dicho Dios mismo: "Buena comparación has hecho; mira no se te olvide..." (Vida, 39, 23).

Santa Teresa ha mostrado también una aguda conciencia fenomenológica del momento creador, hasta tocar el extremo de su oscuro arraigo en un incontrolable proceso biológico. Sus reflexiones nacen aquí de una larga práctica y conocimiento del oficio, en toda su grandeza y miseria. Aprendió a reconocer el rapto de exuberancia o furor poético, cuya rapidez deja atrás a la mano: "Mas ¡qué de cosas se ofrecen en comenzando a tratar de este camino! ¡Ojalá pudiera yo escrivir con muchas manos para que unas por otras no se olvidaran!" (Camino E, 34, 4). Y lo mismo se complacerá también en describir, con la sobria exactitud de siempre, el tan común y temido writer's block: "... que cierto algunas veces tomo el papel como una cosa bova, que ni sé qué decir ni cómo comenzar" (Moradas, I, 2, 7). La experiencia poética es para ella, como para todo creador nato, un goce agridulce, adictivo e insustituible, que llega a colmar la vida: "Doy por bien empleado el tiempo que ocupare en escrivir y tratar con mi pensamiento tan divina materia" (Meditaciones, 1, 9).

Obra y oración han vivido en ella un mutuo equilibrio, estudiado hasta ahora en el único sentido del absoluto ascendiente de lo doctrinal. Pero su mismo alto concepto del tema místico le ha impedido considerar aquellos libros y papeles como simples instrumentos de una comunicación utilitaria. Su vida en la literatura ha sido así una total y satisfactoria plenitud, un foco de clarificación mental y de estabilidad anímica al servicio de su experiencia contemplativa. El futuro estudio de ésta habrá de valorar algún día la medida en que su vida espiritual ha sido sutilmente canalizada también por aquella continua entrega (asimismo iluminativa) a las exigencias del proceso creador.

En el caso de Santa Teresa, la crítica no ha tenido mayores dificultades, ni resgistra tampoco discrepancias, a la hora de darle lo que tan claramente es suyo. Sólo cabe registrar así matices dentro de una 
general aclamación como adalid máxima del socratismo cristiano ${ }^{39}$, la gran investigadora de "le moi profond" 40 , que de pronto se halla con una amplia vía por delante, tras el milenio largo que la separa de San Agustín. En lo filosófico es frecuente pasar de aquí a considerarla como una de las fuentes de la modernidad intelectual, por la deuda que con ella contraen Malebranche, Leibnitz y Pascal ${ }^{4}$. En lo puramente literario se ha insistido con justeza en su función como manantial del ensayismo hispánico ${ }^{42}$, asimilada a Montaigne en su rechazo de la imposición erudita de su época. Apenas si se menciona, en cambio, lo que sus técnicas de análisis psicológico hacen para abrir paso a un nuevo concepto de la novela. Lo que Cervantes (gran admirador de su vida mística) ha podido captar no sólo en su fenomenología del alma, sino en la proyección narrativa de ésta bajo la fórmula paranovelística de la autobiografía, que de un modo u otro cubre casi la totalidad de su obra. Ese "pacto autobiográfico" ${ }^{43}$ de imprevisible pero siempre controlada fluencia, que en cualquier momento elige hacerse arcano o

39 Robert Ricard, "Notas y materiales para el estudio del 'socratismo cristiano' en Santa Teresa y en los espirituales españoles" $B H i, 49$ (1947), 5-37, 170-204; 50 (1948), 5-26; 51 (1949), 407-422.

${ }^{40}$ Hoornaert, Sainte Thérèse écrivain, p. 538. Sobre su yo múltiple, Lucien CaSTe. LA, "Mystique et autobiographie. La 'Vida'de Sainte Thérese", L'autobiographie dans le monde hispanique, Université de Provence, Aix-en-Provence, 1980, p. 139. Sobre modalidades de la autobiografía religiosa de la época y el moi autobiográfico, JEAN Molino, "Strategies de l'autobiographie au Siècle d'Or", ibid., 115-137. Como a nota R ANDOlPh D. POPE, la innovación que la distingue frente a todos sus antecesores en el uso de la autobiografía es su "yo sabía lo secreto de mí" (La autobiografía española hasta Torres Villarroel, Bern-Frankfurt/ M., 1974, p. 71). Más atento a lo biográfico que a lo literario el estudio de Afra Sinnige-Breed, "Evolución normal y unitaria del 'yo' teresiano a la luz de la vida interior", $R E, 22$ (1963), 238-250. El importante papel de la religiosidad intimista en la génesis de la autobiografía hasta su empalme con Rousseau es estudiado (si bien con absurdo olvido del caso teresiano) por George Gusdorf, "De l'autobiographie initiatique à l'autobiographie genre littéraire", Revue d'Histoire Littéraire de la France, 75 (1975), 957-994.

${ }^{41}$ Hoornaert, Sainte Thérèse écrivain, p. 542. Jacques Chevalier, "Sainte Thérèse d'Avila et l'expérience de Dieu”, Histoire de la pensée, Flammarion, Pa ris, 1956, t. 2, p. 686. Alphonse Vermeylen, Sainte Thérèse en France au $x$ vit siècle, Publications Universitaires, Louvain, 1958. Visión restrictiva en Robert Ricard, "Pascal, Santa Teresa y los santos", Studia Hispanica in honorem R. Lapesa, Gredos, Madrid, 1972, t. 1, 439-442. El problema de Santa Teresa en Francia dista todavía de hallarse agotado o satisfactoriamente resuelto. Reflexiones incidentales sobre Descartes y Leibnitz en Argimiro Ruano, Teresa de Ávila clásica, Editorial Edil, Río Piedras, 1972, pp. 136-138. Es curioso comprobar cómo las obras de Santa Teresa ni siquiera faltaban en la biblioteca de Voltaire (F. S. Escribano, "Sobre el posible origen español de la frase 'il faut cultiver notre jardin' de Candide (con un apéndice de las obras españolas o sobre España en la biblioteca de Voltaire)", $H f$, 1964, núm. 22, 15-26.

42 J. Marichal, "Santa Teresa en el ensayismo hispánico", La voluntad de estilo, 103-1 15. Contra G. Etchegoyen, Victor García de la Concha deslinda el sentido de lo moderno y lo medieval en la obra de Santa Teresa (El arte literario de Santa Teresa, p. 107).

${ }^{43}$ Philippe Lejeune, Le pacte autobiographique, Éditions du Seuil, Paris, 1975. 
abrirse a la más gratuita actitud confesional. Puede ésta, a su vez, agotar un simple giro de frase o adjetivación eficaz (como aquel su ser "honrosa"), o explayarse en episodios tan morosa y aun amorosamente analizad os como la historia del clérigo de Becedas (Vida, 5, 3-6), con su delicada objetivación de los sentimientos más crepusculares. Porque en aquel par de páginas está todo: ho mbre y mujer jugando muy en serio al a mor divino, con el a mor humano de por medio; después el aire de clandestinidad impuesto por los tiempos lo mismo a la oración que al erotismo, al espíritu como a la carne; al fondo, la claustrofobia del lugarejo y la peripecia romántica del idolillo maléfico. Es toda una austera novela unamuniana ${ }^{44}$, salvo por su fondo de inmensa ternura, que sólo una mujer (una mujer como ella) podía darle. ¿Y qué necesidad, entonces, de un montón de pliegos emborronados? Si Teresa se sobrepuso, al fin, a tanta morbosidad revestida y anegada de espíritu, sucumbió después, pluma en mano, a la tentación de dársenos (en aquel episodio que no tenía por qué haber contado) ${ }^{45}$ por heroína de una novela psicológica, más que como foco de una cuenta de conciencia al uso común y corriente.

Si existe acuerdo en aceptar su primacía como descubridora del propio yo psicológico, en ella tan rico, dista de haberse agotado la intelección de tamaño logro en su correcta perspectiva históricoliteraria. En ausencia de toda tradición medieval ${ }^{46}$, el misticismo era en España un fenómeno por completo juvenil y sin historia, modelos ni precedentes (Lulio fue nada más que un caso seudomórfico de sufismo cristiano). Impedida Teresa por su condición de mujer sin letras, se libró también de beber en las habituales fuentes neoplatónicas del seudo-Dionisio ${ }^{47}$ ni en las abstracciones de la mística nórdica. Sus únicos y más altos maestros en lo relativo a un concepto de la literatura espiritual vienen determinad os por el obvio cuadrilátero Osuna-Laredo-Granada-Ávila. Pero si bien grandes escritores (y en el caso de Ávila un gran teólogo creador), ninguno de ellos alcanzaría a abordar el tema místico propiamente dicho. El buen fray Francisco de Osuna, como el más despreocupado de los cuatro, se quedará, con su oración

\footnotetext{
${ }^{44}$ Las sugestiones novelísticas del episodio no dejaron de ser captadas por el propio Unamuno, según Arthur A. Nateli.A, "Saint Theresa and Unamuno's San Manuel Bueno, mártir", Papers on Language and Literature, 5 (1969), 458-464.

${ }^{45}$ Sobre la naturaleza y límites del carácter confesional de su obra, CASTELA, "Mystique et autobiographie", p. 146. Interesantes consideraciones sobre la actitud gratuitamente autodelatora en la vida española de la época en Adrienne SchizzanoMANDEL, "Le procès inquisitorial comme acte autobiographique: le cas de Sor María de San Jerónimo", L'autobiographie dans le monde hispanique, 155-169.

46 Acuerdo unánime, sobre este punto, desde Menéndez Pelayo, Historia de las ideas estéticas en España, C.S.I.C., Madrid, 1962, t. 2, p. 80, hasta Américo CAstro, Teresa la Santa y otros ensayos, Alianza Editorial, Madrid, 1982, p. 45.

${ }^{47}$ Francisco González F. Cordero, "La teología espiritual de Santa Teresa, reacción contra el dualismo neoplatónico", $R E T, 30$ (1970), 3-38.
} 
de recogimiento, a las puertas del verdadero fenómeno unitivo, sin ir más allá por falta de experiencia o de capacidad creadora y casi de seguro por ambas cosas a la vez. No así en el caso de San Juan de Ávila, "un hombre tan sobrenatural y todo divino" 48 para fray Luis de Granada, pero convencido de que el tema místico o carismático es, precisamente, lo que jamás debe salir a otra luz que la de la propia conciencia.

Nada de esto rige con Santa Teresa, pues, como observa un moderno estudio ${ }^{49}$, a partir de las quintas Moradas todo es inédito y nada más que suyo. El negarse a entrar, literariamente hablando, en las zonas abisales de la vida contemplativa es así una característica de toda esta generación o período que habría que llamar pre-teresiano. Sus comprensibles motivos son diversos, y en los casos de San Juan de Ávila y de fray Luis de Granada debió de pesar mucho la persuasión de ser todo ello incompatible con las barreras del Santo Oficio y la general reciedumbre de los tiempos. Pero lo que un fenómeno tan absoluto y unánime pone fuera de toda duda es la carencia de capacidad expresiva, esto es, la convicción de que, a ciertas alturas, la vida del espíritu no tiene ni puede tener dimensiones comunicables en un sentido literario normal. De no ser así, cualquiera de aquellos ingenios tenía talento sobrado para cogerle las vueltas a la Inquisición, igual que supo hacerlo la monja escritora. Pero es sólo en este momento cuand o se mide el avance revolucionario y la clase de ruptura supuesta por la actitud teresiana de ir hasta donde hubiera que llegar. Frente a tan altos varones, rebosaba ella de confianza en las posibilidades de su lengua de burguesa abulense, puesta a prueba por las exigencias de la técnica introspectiva en lo relativo a rigor y matización, según tanto admiraba Jean Baruzi ${ }^{50}$.

Lo que nunca se ha entendido acerca de esto es la medida en que dicha ruptura se hallaba bloqueada por un problema fenomenológico no menos poderoso que el de puro lenguaje y comunicación. Y es que la experiencia mística resulta por naturaleza íntima y secreta como

\footnotetext{
48 Álvaro Huerga, "El beato Ávila, imitador de San Pablo", $R E, 9$ (1965), p. 288. Falta un estudio particular sobre la influencia de Ávila en Santa Teresa. Cabe adelantar que no es preciso ir más lejos para hallar la clave de los ecos valdesianos detectados por Antonio Comas, "Espirituales, letrados y confesores en Santa Teresa de Jesús", Homenaje a Jaime Vicens Vives, Facultad de Letras, Barcelona, 1967, t. 2, p. 85. La intensa comunicación de ideas avilinas a Santa Teresa queda fuera de toda duda tras el estudio de José Vicente Rodríguez, "Cinco cartas inéditas de San Juan de Ávila", $R E, 34$ (1975), 344-378.

49 Secundino Castro, "Singularidad de Teresa de Jesús", $R y F, 204$ (1981), p. 336.

50 "Une Sainte Therèse, qui se dérit elle-même et n'aspire quà se manifester telle qu'elle s'aperçoit, fait appel à sa riche imagination pour parvenir à rendre des nuances qui sont indescriptibles. De là son goût de la définition et de la classification. Tous les états qu'elle découvre reģoivent un nom précis, et dont le sens peut être en quelque sort appris, retenu, techniquement utilisé" (Saint Jean de la Croix et le problème de l'expérience mystique, Alean, Paris, 1924, p. 361).
} 
ninguna otra de orden humano (mística y misterio, partes de una misma familia léxica). Santa Teresa no dejó de advertir sobre esta barrera, que su ímpetu creador desafiaba a cada momento: "Quédase tan espantada, que basta una merced de éstas para trocar toda un alma... y le comunica secretos, y trata con ella tanta amistad y amor que no se sufre escrivir" (Vida, 27,9). Hay un sigilo místico que exige la inviolabilidad y el secreto, vocablo este último que es uno de los de mayor circulación en su obra (con más de medio centenar en mi recuento). Incluso el P. Gracián era adverso a lanzar tales margaritas a la intemperie de gentes mundanas y pecadores públicos ${ }^{51}$, pues no en vano el libro de la Vida había sido objeto de irrisión en las caballerizas de la princesa de Éboli. Se da, pues, de esta forma, una contradicción de términos entre el goce del carisma y su publicidad magistral, y esto ha sido también una de las grandes luchas de Santa Teresa, pues como glosa un experto: "Lo místico comparece no sólo con carácter de intimo arcano, sino con pujante exigencia de secreto celado y receloso: tener que decir lo que pasa entre Dios y ella es la agonía cuotidiana de Teresa" $" 52$. Para Osuna, su primer maestro, todo proceder en contrario era una pura insensatez, de la que ningún provecho podía seguirse: "Sano y muy buen consejo es que ponga el hombre todo su sentido y saber para esconder estas cosas" $"$. Pero es San Juan de Ávila quien

\$1 J. Poitrey, “QQué cosa es el 'Libro de la Vida' de Santa Teresa?”, p. 99.

52 Tomás de la CRuz, "Santa Teresa de Jesús contemplativa", EC, 13 (1962), p. 59. Sobre el "sonrojo" de temer la hilaridad de los confesores, ibid., p. 44. La importancia capital de este punto da pie a un amplio florilegio crítico. V. GARCÍA DE LA CONCHA comenta: "Es el desnudar el alma sin pudor y aun con el mayor pudor, haciéndolo por necesidad y suplicando, desde la obediencia, respeto a la intimidad. Pero a la vez aceptando, martirialmente, el que la intimidad pueda trascender, si ello sirve para poner de manifiesto la grandeza misericorde de Dios" (El arte literario de Santa Teresa, p. 197). Dámaso ChICharo: "Ella acepta desnudar su intimidad, contando lo que de suyo es incontable, con el solo fin de manifestar la grandeza de Dios, que tanto bien ha hecho con un alma tan 'ruin' como la suya, y que hará mucho más en las restantes" (Libro de la vida, p. 78). Y en especial los epígrafes "La intimidad sorprendida" y "Confesión lírica" de Américo Castro, "La mística y humana feminidad de Teresa la Santa", Teresa la Santa y otros ensayos, Alianza Editorial, Madrid, 1982, pp. 64-84 (originalmente publicadas en 1929).

${ }_{53}$ Saturnino López Santidrián, "El consuelo espiritual y la hiumanidad de Cristo en un maestro de Sta. Teresa: Fr. Francisco de Osuna", EC, 31 (1980), p. 172. Osuna no se cansa de aconsejar toda suerte de precauciones; los espirituales deben hablar muy poco de sus goces de Dios, y en todo caso dígase como sucedidos a otra persona o por semejanza con pasos de la Escritura (Tercera parte del libro llamado Abecedario espiritual, ed. M. Mir, en Escritores místicos españoles, $N B A E$, Madrid, 1911, t. 1, p. 532). No se hable de estas cosas con los espirituales, que tal vez "piensan ellos que es sueño" (ibid., p. 487). "Lo último avisóte que serás perseguido si descubres estas cosas a quien no deves, según yo lo he visto en muchos que fueron muy afligidos de quien no pensaran por solamente decir la verdad de lo que sentían" (ibid., p. 487). Es preciso administrar el espíritu de caridad en aficionar a otro a estos ejercicios, pues fácilmente cobrará enemistad, "ca no teniendo el corazón aparejado piensa que le amonesta aquello porque lo has visto disoluto y porque eres inquisidor de su vida; e ansí te tiene 
mejor ayuda a comprender esta imperiosa realidad en la advertencia que, con palabras brutales, hacía a cierto discípulo suyo en 1538: "Lo que en su corazón pasa con Dios, cállelo con grande aviso, como debe callar la mujer casada lo que con su marido pasa en la cama" ${ }^{\text {. }}$.

Santa Teresa hablará de la vergüenza intolerable que le causa el continuo dar cuenta de las mercedes recibidas: "Yo solía sentir grandísima contradicción en decirlo" (Vida, 33, 9). Considera por lo mismo una dura prueba el que los carismas se manifiesten a veces en público, lo cual la deja "tan corridísima que me querría meter no sé dónde" (Epistolario, 173, 5). Los Avisos (sean de quien sean) afirman tajantes: "Guarde mucho los sentimientos que el Señor le comunicare" (32). Su Regla no en vano exime de informar al prelado sobre el curso de la propia vida interior ${ }^{55}$ y nadie arrancó a Ana de Jesús Lobera, su mejor discípula, una sola palabra escrita acerca de su altísima oración ${ }^{56}$. Pero Santa Teresa procedió a abrir de par en par los sagrarios de su vida interior y si ello constituía un terrible compromiso, no dejaba de ser a la vez un triunfo infinitamente satisfactorio para su conciencia de escritora. La gran diferencia es que, contra todos sus maestros, cree en el provecho de dar una razón detallada y fiel de la terra incognita que son las más altas experiencias del espíritu. Desde luego, no procede así bajo impulsos de un cultivo desinteresado del arte. Lo hace por legitimar a aquéllas para siempre en el seno de la ortodoxia y por caridad con las almas angustiadas de miedo e incomprensión. En adelante, ninguna conciencia cristiana habrá de sufrir como sufrió la suya, bajo tiranía de manos ignorantes por espacio de tantos años. Y también como auxilio providencial de la Iglesia, vendida a diario por la masa del clero indigno y asediada de herejías, que torpes poderes

por malsín e se guarda de ti"(p. 487). Por todo esto no se deberían descubrir tales cosas sino bajo juramento, porque de ello salen "muchos males tan secretos e solapados e maliciosos, que parescen increíbles; empero la experiencia los ha hecho manifiestos" (ibid., p. 488).

54 Luis Sala Balust, "Vicisitudes del 'Audi, filia' del Maestro Ávila. Diferencias doctrinales en sus dos ediciones", Hispania Sacra, 3 (1950), 65-127. Las versiones conocidas de este texto omiten las palabras finales "en la cama".

55 Tomás DE la Cruz, "El 'voto de obediencia' de Santa Teresa y sus tres relatos autógrafos", $E C, 15$ (1964), p. 174.

56 Según su biógrafo fray ÁNGEL MANRIQUE, escribió por obediencia su fundación de Granada y por ruegos accedió a que se imprimiese. "Mas no se pudo acabar que escribiese las otras, aunque la importunaron hartos a ello, ni uuo Prelado que tuuiesse ánimo de mandárselo" ( La Venerable Madre Ana de Jesús, Bruselas 1632, 1. VII, p. 82). Totalmente enemiga de la idea de tratar sobre materias de espiritu, esquivaba cuanto podía el dar a sus confesores ninguna cuenta por escrito (ibid., l. V, p. 357). Otras veces respondía: "Escrita me vea yo en el libro de la vida, que otros escritos no los apetezco". Y si le insistían en que dejara relación de sus mercedes divinas: "Harto buena estuviera la gloria de Dios, si llegara a necesitar de essas memorias"(Moriones, Ana de Jesús y la herencia teresiana, p. 133). 
terrenales intentan reducir con fuego y soldadescas ${ }^{57}$. El contemplativo no había sido visto nunca como un combatiente ${ }^{58}$, lo mismo que los dones de la vida mística no habían sido parte hasta entonces de la obligada alabanza de Las misericordias de Dios, que fue el título alternativo de su Libro de la vida. Harto bien sabía ella que sus libros no se parecían a ningunos otros y que dicha misión se hallaba hasta el momento del todo incumplida, al menos dentro del marco o contexto que ella se marcaba. Era éste (aunque no lo supiera) esencialmente fenomenológico, existencial y pragmático. Es decir, moderno con todas sus consecuencias. Borrón y cuenta nueva, en lugar del suma y sigue acostumbrado en la literatura religiosa.

En el plano literario tenemos en el fondo lo mismo. La marcha o evolución histórica de la Weltliteratur consiste en la apertura de nuevas zonas de sensibilidad, que de pronto se vuelven significativas y comunicables conforme a profundas e inéditas aspiraciones humanas de los tiempos. Entran en escena creadores privilegiados, dueños de visión y facultades en extraña armonía con anhelos y estados de ánimo existentes, pero a los que sólo ellos acabarán de dar su forma. Tras Santa Teresa se hacen viables muchos nuevos rumbos y para entender su puesto entre estos grandes individualistas o héroes de la poesía, en el sentido más a lo Carlyle, nada quizás más útil que aquellas palabras de San Juan de Ávila acerca de la naturaleza inconfesable ("incomunicadera", en buen castellano) de la intimidad conyugal. Adviértase cómo, en efecto, la consideración positiva del sexo permanece bloqueada para la literatura occidental hasta el advenimiento de la revolución freudiana. Al borde cronológicamente, pero sin entrar en ella, un escritor como Tolstoi ${ }^{59}$ consideraba prueba decisiva del carácter infrahumano de la sexualidad el que sus actos no pudieran ser descritos de modo que no resultara repugnante e irredimible en un plano estético. Sin duda, hablaba de su propia fracasada experiencia ante las cuartillas, lo mismo que los antecesores directos de Santa Teresa, y sobre todo Ávila, no llegaron a considerar hacedera, ni tampoco deseable, la superación de aquella otra muralla defensora del pudor del espíritu.

${ }^{57}$ De acuerdo con la crítica tan hábilmente insinuada en el cap. 3 de Camino de perfección y a partir, una vez más, de bases muy reconocibles en el pensamiento del Maestro Ávila. Igual también su discípula Ana de Jesús Lobera, muy partidaria de la paz política y de la tregua proclamada en Flandes (donde le tocó iniciar la Descalcez), acerca de la cual solía decir: "Dios por su misericordia la perpetúe, que assi fue en Francia, desde que entramos lo uuo; y es mayor bien de que allá [en España] puede pensarse, porque con esto crecen los católicos y se disminuyen los herejes"(ManriQuE, La Venerable Madre Ana de Jesús, 1. VI, p. 40).

${ }_{58}$ En esto, como en tantas otras cosas, parece desarrollar una idea de fray Francisco de Osuna, para quien la experiencia carismática "es de grandissimo provecho e utilidad, no tan solamente al que la tiene, mas a toda la Yglesia"(Tercer abecedario, p. 375).

59 ERnest J. Simmons, "Leo Tolstoy. The later days", The Atlantic Monthly, Sept., 1946, p. 168. 
"Et qu'est-ce que l'histoire d'une littérature, sinon celle de ses révolutions succesives?", se pregunta Paul Benichou ${ }^{60}$. En este caso todo va a cambiar y a parecer, de pronto, hasta natural y fácil con Santa Teresa. Américo Castro ${ }^{61}$ pone aquí el ejemplo de Proust y del Romanticismo, pero es preferible prolongar el iniciado paralelismo con el recuerdo de D. H. Lawrence respecto a la nueva valoración literaria del sexo. Hay cierta ironía paradójica en que sea una mujer enclaustrada, bajo un ambiente misógino e inquisitorial, quien acometa una empresa tan temeraria y de tal modo posibilista. Se ha mencionado antes a Freud, pero con Santa Teresa tendríamos a manera de un desideratum de la nueva filosofía del alma que Luis Vives (el otro gran preocupado con los recovecos del psiquismo $)^{62}$ no en vano tituló De anima et vita. Por detrás de Santa Teresa no deja de alzarse también una gran revolución filosófica. El alma, gran tesis especulativa para la escolástica, se erige ahora en problema y pasa a ser objeto de estudio inmanente, erizado de paradojas, involuciones y aporías de todo género, porque no es ya una gran "solución", sino todo lo contrario. Y no es, claro está, que Santa Teresa haya estudiado a Vives en su celda, a la luz del candil. Pero intuitivamente madrugaba también para compartir un alto interés en lo psicosomático y no podía imaginar el alma en abstracción de lo físico, o desobjetivada de una fluencia vital (la suya propia). Vives y Santa Teresa se enfrentarán con el magno problema planteado por el principio psicosomático (alma + vida) en un terreno todavía, por elección, ortodoxo. No así los médicos filósofos Gómez Pereira y Huarte de San Juan, representantes de la orilla "laica" del mismo pensamiento. Unos y otros, no se pierda de vista, eran conversos ${ }^{63}$.

La Santa reconoció en su quehacer literario una de las decisivas razones de su vida, mezcla de dolor y deleite en perfecta continuidad con la misma experiencia mística que trataba de captar en sus escritos. Más que nunca se hace imposible ver aquí la supuesta eficacia de una intervención de los hombres, pues por propia definición tod o ello fluye de lo que para Santa Teresa es un compromiso personal con Dios. Su esfuerzo creador queda de este modo investido de una crucial tarca apostólica: casi la única destinada a sobrevivir fecundamente de entre

\footnotetext{
60 "Le statut de la littérature", Mélanges offerts à Paul Benichou, Droz, Genève, 1982 , p. 19

${ }_{61}$ "La mística y humana femeninidad de Teresa la Santa", Teresa la Santa, p. 73

${ }^{62}$ La notable correlación de Santa Teresa con el realismo psicológico de Vives fue la notada por Hoornaert (Sainte Thérese écrivain, p. 540).

${ }_{63}$ Como acaba de observar Melquíades Andrés Martín, el reformismo español de la época "contaba con una antropología sobre el valor de lo corporal y sensible por causa de su convivencia secular con los árabes y judíos $\mathrm{y}$, sobre todo, por el hecho masivo, único en Europa, de los conversos con su tendencia a encerrarse en grupos de ascendencia racial y a supervalorar lo interior y el amor frente a su antiguo ceremonialismo" ("Los alumbrados de Toledo en el 'Cuarto abecedario, o ley de amor' de Francisco de Osuna (1530)", $A I A, 41,1981$, p. 462).
} 
el fango y las llamas de la crisis religiosa de su época. Tales son los supuestos que en ella moldearon para el mundo el primer arquetipo de escritora moderna, integralmente dada a su pluma, no menos que asentada en su condición de mujer. Fiel a su vocación, vivió los altibajos de un cumplido profesionalismo, en el que no faltan facetas tan a lo nuestro como la de admiradora ansiosa de cartearse con tan distinguido colega como fray Luis de Granada ${ }^{64}$, o su irresistible preferencia por la discretísima monjita María de San José ${ }^{65}$, escritora también de singular encanto. Debatiéndose sin complacencias en las encrucijadas más difíciles del siglo, su obra se alza como un alegato por la libertad del espíritu, fuente de toda dignidad humana, y como desafío asimismo al mito sacralizado de la superioridad masculina: "Que tampoco no hemos de quedar las mujeres tan fuera de gozar las riquezas del Señor" (Meditaciones sobre los cantares, 1,9). Pensaba lo mismo que la monja de Ávila, aunque no se atrevió tal vez a decirlo con aquella claridad, una ilustre hermana en las Letras, Margarita de Angulema, reina de Navarra ${ }^{66}$.

No es preciso recurrir, por tanto, a la menor perspectiva hagiográfica para que el caso teresiano se perfile como extraordinario con los más firmes trazos. Porque también es cierto que toda vocación literaria es, vista de cerca, una aventura personal y única, en la que el hombre o la mujer han de dar completo testimonio de sí mismos, a la vez que de sus tiempos. La vocación literaria de Santa Teresa es un fenómeno claro y pujante como la obra a que dio paso, una realidad cuyos límites de comprensión y estudio se perfilan, a la postre, como similares a los de cualquier otro gran ingenio creador. Y no se trata de negar, tampoco, que desde otro punto de vista no menos válido, determine todo ello un milagro ante el que sea preciso enmudecer, pero que no deja de configurarse como el eterno milagro en que empieza y termina el Arte.

Francisco Márquez Villanueva

Harvard University.

${ }^{64}$ Desde Beas, en mayo de 1575 (Epistolario, 80). Una vez más, conciencia de dar un paso muy at revido para una mujer, por lo cual pone por delante "que el señor don Teotonio me ha mandado escrivir ésta" $(80,3)$. Y antes ha dicho, con toda claridad, "que por ningún trabajo huviera dejado de ver a quien tanto me consuela oir sus palabras, si se sufriera conforme a mi estado y ser mujer" $(80,2)$.

${ }^{65}$ Figura muy merecedora de estudio particular, sobre todo en el aspecto literario. Datos bibliográficos en Simeón de la Sagrada Familia, "Prima Instructivo Novitiarum Carmeli Teresiani”, EC, 15 (1964), 130-134. Netamente feminista y reflejo fiel de su maestra, protestaba a las claras la "ley que ha hecho la costumbre" y por la cual parece que a las mujeres "les es vedado el escribir" (Libro de recreaciones, en Humory espiritualidad en la escuela teresiana primitiva. p. 160).

${ }^{66}$ Émile Telle, L'oeuvre de Marguerite d'Angoulême reine de Navarre et la querelle des femmes, Toulouse, 1937, p. 377. 